\title{
Use of Video Blogs in Alleviating Public Speaking Anxiety among ESL Learners
}

\section{Noor Alhusna Madzlan ${ }^{1 \rtimes}$ \\ Goh Hock Seng ${ }^{2}$ Hema Vanita Kesevan ${ }^{3}$}

${ }_{1,2,3}$ Department of English Language and Literature, Faculty of Languages and Communication, Sultan Idris Education University, Malaysia.

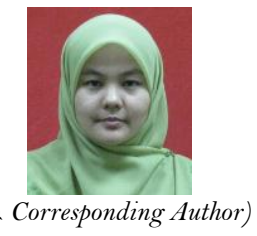

\begin{abstract}
Speaking ability is one of the integral language components in English language acquisition. This ability is a challenging one to master for ESL learners, as it involves several linguistic and nonlinguistic features in presenting ideas and it is frequently associated with anxiety. Public speaking anxiety is a common issue faced by students learning a second language. Feelings such as stage fright and nervousness could contribute to their anxiety in communicating using the target language. Additionally, the classroom environment, the presence of the instructor and peer pressure could also be factors which pose a threat for students, particularly in public speaking settings. The present study aims to investigate whether public speaking anxiety can be alleviated through the use of online platforms and/ or video blogs. The creation of personal video blogs could potentially help learners by providing a safe and non-threatening learning environment in which to practise their public speaking skills. This study also aims to identify the factors that influence the use of video blogs as a public speaking platform. A mixed-method approach is designed to examine the effects of using video blogs. A set of questionnaires and semi-structured interviews were applied to groups of tertiary level ESL learners. Quantitative and qualitative approaches to data analysis were carried out and the results indicate that the use of video blogs does bring significant positive outcomes in reducing public speaking anxiety among ESL learners.
\end{abstract}

Keywords: Public speaking anxiety, Video blogs, Language learning environment

Citation | Noor Alhusna Madzlan; Goh Hock Seng; Hema Vanita Kesevan (2020). Use of Video Blogs in Alleviating Public Speaking Anxiety among ESL Learners. Journal of Education and e-Learning Research, 7(1): 93-99.

History:

Received: 11 January 2020

Revised: 18 February 2020

Accepted: 20 March 2020

Published: 13 April 2020

Licensed: This work is licensed under a Creative Commons Attribution 3.0 License (cc) EY

Publisher: Asian Online Journal Publishing Group
Acknowledgement: All authors contributed to the conception and design of the study.

Funding: The research is financed by the Research Management and Innovation Centre of Sultan Idris Education University under GPU grant. No. 2018-0218-107-01.

Competing Interests: The authors declare that they have no conflict of interests.

Transparency: The authors confirm that the manuscript is an honest, accurate, and transparent account of the study was reported; that no vital features of the study have been omitted; and that any discrepancies from the study as planned have been explained.

Ethical: This study follows all ethical practices during writing.

\section{Contents}

1. Introduction

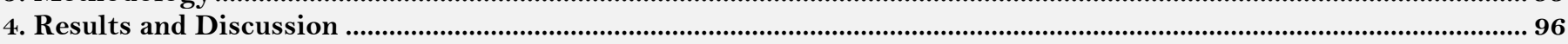

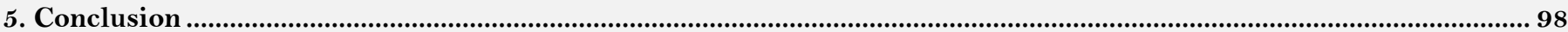

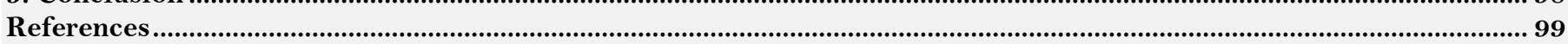




\section{Contribution of this paper to the literature}

This study contributes to the existing literature by investigating whether public speaking anxiety can be alleviated through the use of online platforms and/ or video blogs.

\section{Introduction}

Language components in the English language comprise of four main areas, namely speaking, writing, listening and reading. While listening and reading are categorised as receptive skills, writing and speaking are seen as productive skills. Although learners have the most difficulty in producing written material using the target language, it is perceived that speaking ability is no less challenging to master (Bygate, 2006). Complexities in using accurate linguistic, non-linguistic and paralinguistic features during speech are common challenges faced by ESL learners. Additionally, Nurul (2010) mentions that L2 learners lack confidence in conversing using the target language due to the notion of language interference. This native language interference may hinder the ability to fully master speaking skills. Therefore, these factors may contribute to ESL learners' apprehension about improving their speaking ability.

An important, non-linguistic element that is of equal importance for language acquisition is the affective state of learners. In Krashen (1982) Affective Filter Hypothesis, anxiety acts as one of the filters that may hinder students' language acquisition. In public speaking settings, learners often face difficulties in using the target language due to the nature of 'open talk', where this environment creates room for judgment not only of ideas, but also of appearances. This non-conducive environment is seen as an integral factor that may also cause speaking apprehension among L2 learners.

One possible way to overcome the environmental factor of the speaking anxiety experienced by ESL learners is through the use of Computer-Mediated Communication (CMC). Learners may find this mediating platform to be a good alternative as CMC provides an environment that poses minimal threats. Threats, in this context, may mean the instructor or peer pressure during speaking practices in classrooms; a threat that is often prevalent in teacheroriented environments. Additionally, Satar and Özdener (2008) state that CMC could become an efficient tool as it allows more time for a learner to practice and prepare for their speech. This could avoid potential judgments from the audience, which can, in turn reduce anxiety and boost confidence when speaking. One notable CMC platform is an online video-based system named video blogs. Watkins (2012) states that video blogs (in short, vlogs) are textbased blogs in the form of videos, whereas 'vlogging' is an act of candidly recording videos on matters of interest and posting the content on the internet. One popular website that supports this media content sharing, among others, is YouTube. Video blogs have garnered vast attention and interest, not only for the masses, but also among educators. These video blogs are user-friendly, flexible in terms of content production, interactive and beneficial in facilitating language learning. This digital learning environment is aligned to the needs of Education 4.0, especially at tertiary level. This video blog platform is usually chosen as the medium of speech for the public speaking experience of learners as it can positively affect their willingness to communicate by providing a safe environment for self-expression and peer interaction (Alm, 2009). Therefore, this study introduces the video blog platform, allowing students to deliver their speeches in a non-threatening environment and hence, alleviate speaking anxiety among them.

Several studies have investigated the perceptions and effectiveness of video blogs in enhancing language skills, in particular, public speaking performance (Balakrishnan, 2013; Hung, 2011; Shih, 2010). In the Malaysian context, there are past studies on ESL learner public speaking skills in schools (Hiew, 2012; Lim \& Budin, 2014) and tertiary institutions (Al-Tamimi \& Shuib, 2016; Zhiping \& Paramasivam, 2013). However, there is still a dearth of research on lowering the anxiety of learners when speaking in public settings through the use of technology, namely video blogs.

This study aims to address this issue by highlighting two key objectives as below:

a) To examine the significant difference between the mean scores of anxiety levels before and after the use of video blogs.

b) To identify factors those influence the use of video blogs as a public speaking platform.

Thus, this study attempts to answer the following research questions:

a) Is there a significant difference between the mean scores of anxiety levels before and after the use of video blogs?

b) What are the factors that influence the use of video blogs as a public speaking platform?

\section{Literature Review}

\subsection{Public Speaking Anxiety}

In human communication people experience anxiety, not only in social contexts but also in academic settings. This is not unusual in second language classrooms, where learners experience anxiety when carrying out classroom tasks. MacIntyre, Noels, and Clément (1997) noted that anxiety commonly happens when learners underestimate or over-estimate their language abilities when performing tasks. Similarly, Arafah, Yassi, and Imran (2016) argue that learners may experience nervousness according to different contexts and audiences; by which they may experience greater anxiety in speaking in classrooms compared to speaking within other social groups. Huang (2015) also argues that some students experience challenging situations when speaking in classrooms as they need to constantly compete with others who may be more proficient speakers in the target language. While completing a public speaking task in a language classroom, anxiety is caused by several factors (Aida, 1994):

a. Potential for inadequate performance by evaluator or instructor.

b. Fear of negative judgments and evaluations by audience.

c. Fear of repeating past failures.

These factors can lead to increased anxiety among students in language classrooms. Thus, the present study proposes an alternative learning environment where learners may potentially reduce their anxiety when addressing an audience, through using a virtual setting during a public speaking task. The virtual environment is a form of computer mediated communication. 


\subsection{Computer-Mediated Communication}

Computer-Mediated Communication (CMC) is a type of human communication that is aided by computers and technology (McQuail, 2005). By incorporating technology in language learning, students are able to benefit from the learning experience through active participation in tasks that require the use of the target language. In public speaking settings, the classroom environment may not be conducive for learners as they are subjected to audience judgment and teacher expectation that could affect their speaking ability and level of nervousness. This current work aims to provide an alternative environment to enable students to speak publicly using the target language in a less threatening environment through the use of a video-based online platform.

\subsection{Use of Video Blogs in CMC}

A video blog, considered as part of Asynchronous Computer-Mediated Communication (ASCMC), is an online environment that allows people to delay their response to online interactions. This is beneficial, especially for learners with anxiety, since it enables them to plan and present their speeches without interruption from other parties. Hsu (2016) mentions that video blogs have been widely applied in language education, particularly to assist learners with low proficiency, as the environment poses a safe and low threat atmosphere in which they can practice their target language. Gokturk (2016) investigated the use of video blogs in EFL learners and found that there was improvement in their oral proficiency and risk-taking during spoken interaction of this nature. This present study aims to extend the findings of Gokturk (2016) by examining the use of video blogs in relation to learner anxiety in public speaking settings.

\subsection{Theoretical Underpinning}

This study applies the main theories of work from Krashen (1982) in his Affective Filter Hypothesis, along with the Connectivism theory developed by Siemens (2005) as a learning theory with the integration of technology in a digitalised and connected world.

\subsection{Affective Filter Hypothesis}

The present study applies the main theory of work from the Affective Filter Hypothesis, developed by Krashen (1982). The theory centres on the relationship between several affective variables and second language acquisition. These variables include motivation, attitude and anxiety. According to Krashen, language competence can be achieved if barriers in language, which act as filters, are minimised. Krashen also argues that learners with high motivation and self-confidence along with a low level of anxiety are seen as better equipped to successfully acquire a second language.

In the model, the learner receives comprehensible input. The input, however, may be filtered due to one or more affective variables, which in this case is speaking anxiety. A Language Acquisition Device, which is a theoretical component of the learner's thought, in other words an instinctive mental capacity to acquire knowledge, and then facilitates achieving the required competence. Hung (2011) mentions that video blogging fulfils the Affective Filter Hypothesis by promoting a motivating learning environment due to the interactivity that appeals to the digital age generation. For this study, this model is relevant to further understand whether the anxiety filter could be lowered through the use of video blogs to assist in acquiring public speaking skills.

\subsection{Connectivism}

Connectivism is related to the notion of utilising technology to make connections in the learning environment in order to shift the learning theories into the digital age (Siemens, 2005). Siemens (2005) stated that learning occurs when there is a shifting of environments by focusing on the connections that enable people to increase their learning experience. One of the principles of connectivism, that is applied in the present study, of video blogs and video blogging activity is that learning is a process of connecting information sources. This implies that learning can take place when people connect with each other to obtain and share information. This is related to video blogging activity whereby, through this platform, people share information in the form of video.

Connectivism also advocates the use of social networks to understand learning in the digital age. The interdependence between people connected through this social networking enables the knowledge and information to flow and allows learners to remain current (Siemens, 2005). This theory is conceptualised in the study whereby language learners not only disseminate information, but they also form connections with others through the online platform of video blogs.

\section{Methodology}

An embedded, sequential mixed-method research design (Creswell \& Clark, 2007) will be adopted to investigate the research issue addressed in this study. In this design, both quantitative and qualitative data are collected and analysed. While quantitative data is given primary emphasis, the qualitative findings are also pertinent to provide support for drawing useful conclusions of this study.

This design is mainly used to examine the impact of the intervention. In the context of the present study, the intervention is the use of video blogs to deliver a public speech. 54 first year, tertiary level ESL learners were involved in the study. Two intact groups were formed with 24 learners in one group and 30 in the other group. The 30 participants in the larger group were randomly assigned to be part of the treatment group, whereas the 24 participants in the smaller group were assigned to the control group. The intervention was conducted over a span of four weeks, where participants from the treatment group were required to produce three video blog entries per week. Themes for each video blog were suggested, but not confined to, topics sourced from the Listening and Speaking Workbook by Oxford Press (Earle-Carlin, Snow, Zwier, \& Zimmerman, 2011). Additionally, participants from the treatment group were required to $\log$ their experiences into their reflective journals after the video blogging activity. The reason for this additional task of writing journal reflections was to facilitate triangulation of data to measure the effectiveness of the intervention. 
For instrumentation, a Personal Report of Public Speaking Anxiety (PRPSA) questionnaire was adapted for this study. The PRPSA survey was developed by McCroskey (2013) and consisted of 34 items, with 22 negative constructs and 12 positive constructs. A measure of reliability was conducted on the instrument using Cronbach Alpha to obtain the internal consistency of the constructs in the adapted questionnaire. The Cronbach Alpha analysis returned a score of 0.92 , which was interpreted as excellent consistency between the item constructs (Bond \& Fox, 2007). This suggested that the questionnaire was reliable enough to be utilised in the study.

The PRPSA scoring method was formulated through this criterion: [PRPSA $=72-$ Positive items + Negative Items]. The total score was expected between 34 and 170 . The scoring method is displayed in Table 1:

\begin{tabular}{l|c}
\multicolumn{2}{c}{ Table-1. PRPSA scoring method. } \\
\hline Anxiety Level & Score \\
\hline High & $>131$ \\
\hline Moderate & $98-131$ \\
\hline Low & $<98$ \\
\hline Source: McCroskey (2013).
\end{tabular}

Following intervention, the same questionnaire was administered as a post-measure to compare the level of public speaking anxiety among the participants. Significant differences between the pre- and post- surveys were measured by means of an independent t-test. Results from the surveys provided conclusions to the first research objective; to investigate differences in the levels of speaking anxiety in learners both before and after using video blogs to completetheir public speaking tasks.

A semi-structured interview of selected participants was also conducted to obtain qualitative findings. The interview probed into participant experience using video blogs through one-to-one interviews. Through this method, participants shared factors that influenced their use of video blogs as public speaking platforms. The interview consisted of 10 questions and each session lasted approximately 30 minutes. The data obtained from these interview sessions were transcribed and analysed qualitatively to acquire answers to the second research objective; to identify the factors that influence the use of video blogs as a public speaking platform.

\section{Results and Discussion}

To answer the first research objective, to examine the significant difference between the mean scores of anxiety levels before and after the use of video blogs, a hypothesis testing procedure was established as follows:

Null Hypothesis (Ho): there is no significant difference between the mean scores of the control and treatment groups in their anxiety levels before and after the use of video blogs

Alternative Hypothesis (H1): there is a significant difference between the mean scores of the control and treatment groups in their anxiety levels before and after the use of video blogs

Prior to presenting the result of the hypothesis, an initial descriptive analysis was conducted by categorising anxiety levels ranging from low to moderate to high, for the pre- and post- measures from both the control and treatment groups. The results are displayed in Table 2:

Table-2. Anxiety levels for pre- and post- measurements between groups

\begin{tabular}{l|l|c|c|c|c}
\hline \multirow{2}{*}{ Group } & \multirow{2}{*}{ Level } & \multicolumn{2}{|c|}{ Pre-Test } & \multicolumn{2}{c}{ Post-Test } \\
\cline { 3 - 6 } & & Frequency & Percent & Frequency & Percent \\
\hline \multirow{4}{*}{ Control } & Low & 2 & 8.7 & 3 & 13.0 \\
\cline { 2 - 6 } & Moderate & 13 & 56.5 & 14 & 60.9 \\
\cline { 2 - 6 } & High & 8 & 34.8 & 6 & 26.1 \\
\hline \multirow{2}{*}{ Treatment } & Low & 3 & 10.0 & 14 & 46.7 \\
\cline { 2 - 6 } & Moderate & 19 & 63.3 & 15 & 50.0 \\
\cline { 2 - 6 } & High & 8 & 26.7 & 1 & 3.3 \\
\hline
\end{tabular}

Whereas Table 3 shows the mean and standard deviations for both groups in the pre- and post- measurements:

Table-3. Sample descriptives for pre- and post- measurements

\begin{tabular}{l|l|l|l|l}
\hline \multirow{2}{*}{ Group } & Pre-Test & Post-Test & \\
\cline { 2 - 5 } & M & SD & M & SD \\
\hline Control & 120.78 & 19.08 & 118.52 & 20.24 \\
\hline Treatment & 116.87 & 16.04 & 101.80 & 20.07 \\
\hline
\end{tabular}

Inferential statistical analysis was further applied. An independent t-test was conducted to compare anxiety levels of the control and treatment groups prior to the intervention. Findings from the test suggested that there was no significant difference between the control group $(\mathrm{M}=120.78, \mathrm{SD}=19.08)$ and the treatment group $(\mathrm{M}=116.87, \mathrm{SD}=16.04)$ conditions; $\mathrm{t}(51=0.81, \mathrm{p}=0.421)$. This could be interpreted as meaning that the mean scores of the control and treatment groups were similar in their anxiety levels prior to the use of video blogs in their public speeches. Table 4 shows the results of the t-test for the pre-measurement: 


\begin{tabular}{|c|c|c|c|c|c|c|c|c|c|c|}
\hline & & \multicolumn{4}{|c|}{$\begin{array}{|lc|}\text { Levene's Test } & \text { for } \\
\text { Equality of Variances } & \\
\end{array}$} & \multicolumn{5}{|c|}{ t-test for Equality of Means } \\
\hline & & \multirow[b]{2}{*}{$\mathbf{F}$} & \multirow[b]{2}{*}{ Sig. } & \multirow[b]{2}{*}{$\mathbf{t}$} & \multirow[b]{2}{*}{ df } & \multirow{2}{*}{$\begin{array}{l}\text { Sig. } \\
(2- \\
\text { tailed) }\end{array}$} & \multirow{2}{*}{$\begin{array}{l}\text { Mean } \\
\text { Difference }\end{array}$} & \multirow{2}{*}{$\begin{array}{l}\text { Std. Error } \\
\text { Difference }\end{array}$} & \multicolumn{2}{|c|}{$\begin{array}{l}95 \% \text { Confidence Interval } \\
\text { of the Difference } \\
\end{array}$} \\
\hline & & & & & & & & & Lower & Upper \\
\hline \multirow[t]{2}{*}{$\begin{array}{l}\text { Pre- } \\
\text { Score }\end{array}$} & $\begin{array}{l}\text { Equal variances } \\
\text { assumed }\end{array}$ & .704 & .405 & .811 & 51 & .421 & 3.91594 & 4.82748 & -5.77564 & 13.60752 \\
\hline & $\begin{array}{l}\text { Equal variances } \\
\text { not assumed }\end{array}$ & & & .793 & 42.776 & .432 & 3.91594 & 4.94050 & -6.04904 & 13.88093 \\
\hline
\end{tabular}

Following intervention, an independent samples t-test was conducted to compare anxiety levels of the control and treatment groups after intervention. Findings suggested that there was a significant difference between the anxiety levels of the control group and the treatment group $[\mathrm{t}(51)=2.996, \mathrm{p}=0.04]$. This outcome indicated that participants from the treatment group $[\mathrm{M}=101.80, \mathrm{SD}=20.06]$ showed a lower level of anxiety compared with participants from the control group $[\mathrm{M}=118.51, \mathrm{SD}=20.23]$ after the use of video blogs in their public speeches. Table 5 shows the results of the t-test for the post-measurement:

Table-5. Independent samples t-test on mean scores post-measurement

\begin{tabular}{|c|c|c|c|c|c|c|c|c|c|c|}
\hline & & \multicolumn{4}{|c|}{$\begin{array}{l}\text { Levene's Test for } \\
\text { Equality of Variances }\end{array}$} & \multicolumn{5}{|c|}{ t-test for Equality of Means } \\
\hline & & \multirow[b]{2}{*}{$\mathbf{F}$} & \multirow[b]{2}{*}{ Sig. } & \multirow[b]{2}{*}{$\mathbf{t}$} & \multirow[b]{2}{*}{ df } & \multirow{2}{*}{$\begin{array}{l}\text { Sig. (2- } \\
\text { tailed) }\end{array}$} & \multirow{2}{*}{$\begin{array}{l}\text { Mean } \\
\text { Difference }\end{array}$} & \multirow{2}{*}{$\begin{array}{l}\text { Std. Error } \\
\text { Difference }\end{array}$} & \multicolumn{2}{|c|}{$\begin{array}{l}95 \% \text { Confidence Interval } \\
\text { of the Difference }\end{array}$} \\
\hline & & & & & & & & & Lower & Upper \\
\hline \multirow[t]{2}{*}{$\begin{array}{l}\text { Post } \\
\text { Score }\end{array}$} & $\begin{array}{l}\text { Equal variances } \\
\text { assumed }\end{array}$ & .001 & .976 & 2.996 & 51 & .004 & 16.72174 & 5.58204 & 5.51532 & 27.92816 \\
\hline & $\begin{array}{l}\text { Equal variances } \\
\text { not assumed }\end{array}$ & & & 2.992 & 47.282 & .004 & 16.72174 & 5.58850 & 5.48089 & 27.96259 \\
\hline
\end{tabular}

Figure 1 presents the differences in anxiety levels between each group. Therefore, to answer the first research question, it is hypothesised that there is a significant difference between the mean scores of the control and treatment groups in their anxiety levels before and after the use of video blogs, thus the null hypothesis is rejected.

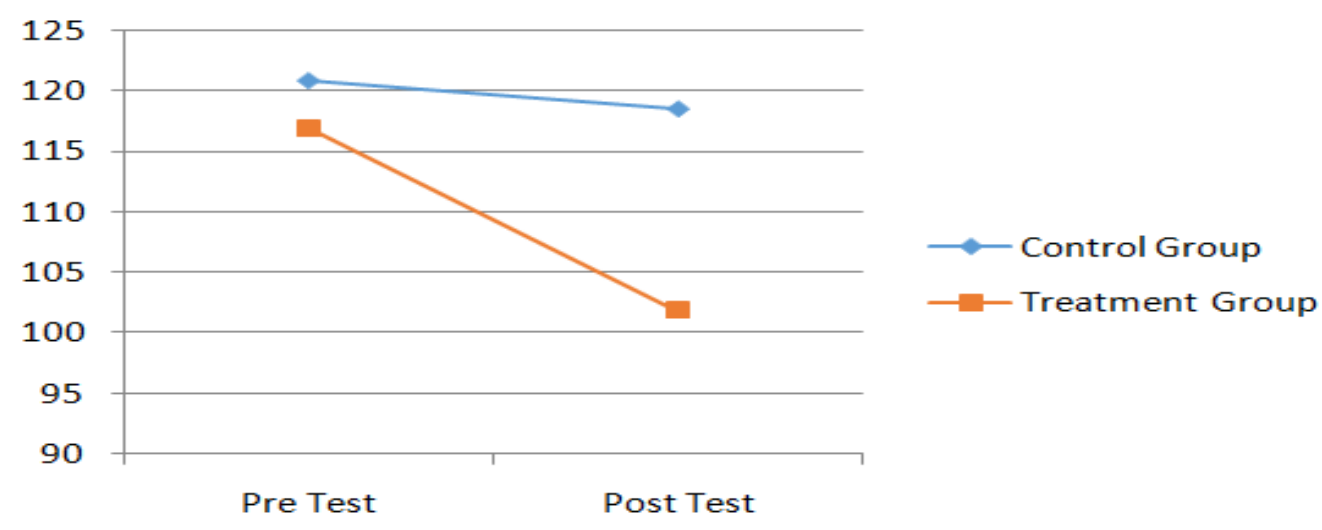

Figure-1. Difference in anxiety levels of both groups before and after intervention.

To answer the second research question, which is to identify factors that influence the use of video blogs as a public speaking platform, responses from participants were recorded in the form of a reflective journal and a semistructured interview. Findings from the reflective journal entries indicated that the environmental factor may influence the anxiety level of participants. Initially, they struggled in adapting to the new environment, but they gradually adjusted well and became more comfortable speaking on camera. Meanwhile, other participants became anxious for fear of being judged by the online audience. Table 6 summarises these responses:

\begin{tabular}{l|l}
\hline \multicolumn{2}{c}{ Table-6. Reflection on speaking anxiety using video blogs. } \\
\hline Participant & Reflection \\
\hline S22 & $\begin{array}{l}\text { I overcame my anxiety a little by talking to my camera. But I did have a short pause between } \\
\text { speeches because I was still nervous. }\end{array}$ \\
\hline S27 & $\begin{array}{l}\text { I was quite nervous while talking in front of the camera. Thinking about how people would judge } \\
\text { me always came to mind. I had to do a few retakes. }\end{array}$ \\
\hline
\end{tabular}

Feedback from Table 6 suggests that students found video blogging to be a difficult experience at first, but eventually it became a safe place for them to practise public speaking, as indicated by S27 where the participant felt at ease when speaking through that platform. This finding is also in agreement with Hsu (2016) where environmental factors play an integral role for language learning. Hsu (2016) claims that when the environment provides a safe and less-threatening atmosphere, language learners can practise their target language better. This is true in the experiences of the participants of this study where they felt comfortable using this online platform while practising their public speaking skills. 
Aside from the environmental factor, the absence of an audience is another factor that influenced public speaking anxiety through video blogs. In an interview session, one of the participants shared that due to the nature of video blogging, there is no live audience when speaking, and this is a different situation compared with traditional speaking settings.

Table 7 provides responses related to an audience as a factor for speaking anxiety:

Table-7. Absence of an audience in video blogs

\begin{tabular}{l|l}
\hline Participant & Response \\
\hline So2 & $\begin{array}{l}\text { I think it's easier to record myself when there's no audience... and you can... I can be } \\
\text { myself... like I can do whatever I want to do and no one is judging me... even if they do } \\
\text { judge me I don't see them judging, you know. }\end{array}$ \\
\hline So3 & $\begin{array}{l}\text { I can't see their facial expressions, so I can't see what they're thinking. If we are talking } \\
\text { face-to-face, I can make (the conversation) more engaging. But as opposed to video } \\
\text { blogging, I can't see my audience, and it is kind of different. }\end{array}$ \\
\hline So7 & $\begin{array}{l}\text { You can't see the audience's facial expressions and what they think about your speech. } \\
\text { having one of your friends in front, in the audience so you can stare at her, see her, so that } \\
\text { she can give you some motivation for yourself to talk and... be more confident. }\end{array}$ \\
\hline
\end{tabular}

Table 7 indicates mixed responses on the public speaking anxiety of participants when there is an absence of audience in the video blog setting. Some respondents indicated that they preferred this online setting where there is no audience. They felt more comfortable with giving their speech while not having to face their audience, due to fear of judgment. Aida (1994) states that the fear of negative judgments from an audience is a major cause of anxiety. This is contrary to the participant's feedback, by which she indicates that she feels less anxious when there is no audience in the video blog platform, as she could be herself.

Meanwhile, other participants (refer to responses from S03 and So5, in Table 6) preferred a live audience during public speaking sessions as they welcomed non-verbal forms of feedback, such as the audience's facial expressions, so they would become motivated and confident enough to continue their speeches. Facial expressions are believed to be effective in relaying non-verbal information (Bambaeeroo \& Shokrpour, 2017). This is supported by Madzlan and Kesevan (2018) whereby effective expression of non-verbal signals is pivotal to conveying information. This absence of an audience in video blogging activities lacks pertinent, non-verbal feedback that is necessary for the speaker during public speaking scenarios.

Another factor that influences public speaking anxiety using video blogs is its role in practising the target language itself, primarily on the speaking components such as pronunciation and grammatical accuracy. Language proficiency, or lack thereof, is a major cause of anxiety among ESL learners. This is apparent in the following participant responses in Table 8:

Table-8. Language use in video blogs.

\begin{tabular}{l|l}
\hline Participant & Response \\
\hline So4 & I don't really care about pronunciation because the vlog is very spontaneous. \\
\hline So6 & $\begin{array}{l}\text { Like if you can't get the right pronunciation, people might misunderstand what you are } \\
\text { going to say. So that might be a problem and make me anxious. }\end{array}$ \\
\hline S10 & $\begin{array}{l}\text { I don't know, I feel confident talking about the topic 'cause I'm afraid if I do like, um, is my } \\
\text { pronunciation okay? Am I talking clearly? So pronunciation is very important. Also your } \\
\text { grammar. I hate grammar mistakes. }\end{array}$ \\
\hline So7 & $\begin{array}{l}\text { When you are watching your own video, you'll instantly understand what were you talking } \\
\text { about before and sometimes you will notice that "I have said this sentence wrong" and "I } \\
\text { feel like this is grammatically wrong" }\end{array}$ \\
\hline
\end{tabular}

Feedbacks from the participants in Table 8 signify that language use is essential for ESL learners and being self-conscious about mistakes made in the target language is believed to contribute to anxiety. Speaking components, such as pronunciation and grammar, are given emphasis by these speakers, and the fear of making mistakes during speeches could hamper their confidence. Interestingly, a participant mentioned that the nature of video, where it is recorded and stays permanently in a specific online channel, allows for her to self-correct her language. This is beneficial, especially for ESL learners, to improve on their language accuracy, particularly in grammar and pronunciation. In contrast, spontaneous speech in natural settings would not allow for students to re-encounter their speaking performance and reflect upon it in order to make improvements to their speaking ability. Hence, video blogs are arguably effective platforms for ESL learners to improve their language use in public speaking.

\section{Conclusion}

Overall, it can be concluded that video blogs play a significant role in reducing the public speaking anxiety of language learners. Findings revealed that students in the treatment group obvserved that their public speaking anxiety decreased significantly after conducting video blogging activity, compared with the control group which did not conduct any such activity. Participants from the treatment group also mentioned that they felt less anxious speaking through this online platform. Although some participants still felt camera-conscious and nervous to start with, after several trials they were able to become increasingly comfortable in this less invasive environment. Based on the findings, it is concluded that video blogs do play a significant role in alleviating the public speaking anxiety of ESL learners, and that through this alternative platform, language learners could potentially increase their levels of confidence in public speaking settings. 


\section{References}

Aida, Y. (1994). Examination of Horwitz, Horwitz, and Cope's construct of foreign language anxiety: The case of students of Japanese. The Modern Language Journal, 78(2), 155-168.Available at: https://doi.org/10.1111/j.1540-4781.1994.tbo2026.x.

Al-Tamimi, A., \& Shuib, M. (2016). Public speaking skills needs of English majors at UniversitiSains Malaysia. LSP International Journal, 3(1), 31-42.Available at: https://doi.org/10.11113/lspi.v3n1.32.

Alm, A. (2009). Blogging for self-determination with L2 learner journals. In Handbook of research on Web 2.0 and second language learning (pp. 202-222). Hershey: IGI Global.

Arafah, B., Yassi, H., \& Imran, N. (2016). Correlation between level of anxiety and public speaking performance through systematic learning approach in foreign language. International Journal of Science and Research, 5(9), 1658-1663.

Balakrishnan, V. D. (2013). Students' perception on learning public speaking skills using face-to-face communication and video blogging.

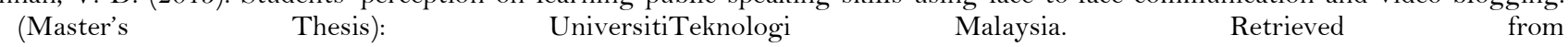
http://www.fp.utm.my/epusatsumber/pdffail/ptkghdfwP2/Vimala\%20Devi\%20AP\%20Balakrishnan.TP.pdf.

Bambaeeroo, F., \& Shokrpour, N. (2017). The impact of the teachers' non-verbal communication on success in teaching. Journal of Advances in Medical Education \& Professionalism, 5(2), 51-59.

Bond, T. G., \& Fox, C. M. (2007). Applying the Rasch model : Fundamental measurement in the human sciences (2nd ed.). New Jersey: Lawrence Erlbaum Associates.

Bygate, M. (2006). Areas of research that influence L2 speaking instruction. In E.U. Juan \& A. M. Flor (Eds.), Current Trends in the Development and Teaching of the Four Language Skills (pp. 159-186). Berlin: Mouton de Gruyter.

Creswell, J. W., \& Clark, V. L. P. (2007). Designing and conducting mixed methods research. LA: Sage Publications.

Earle-Carlin, S., Snow, M. A., Zwier, L. J., \& Zimmerman, C. B. (2011). Q: Skills for success. Listening and speaking: Oxford: Oxford University Press.

Gokturk, N. (2016). Examining the effectiveness of digital video recordings on oral performance of EFL learners. Teaching English with Technology, 16(2), 71-96.

Hiew, W. (2012). English language teaching and learning issues in Malaysia: Learners' perceptions via Facebook dialogue journal. Researchers World, 3(1), 11-19.

Hsu, H. C. (2016). Voice blogging and L2 speaking performance. Computer Assisted Language Learning, 21(2), 18 1-198.

Huang, H. C. (2015). From web-based readers to voice bloggers: EFL learners' perspectives. Computer-Assisted Language Learning, 28(2), 145170.Available at: https://doi.org/10.1080/09588221.2013.803983.

Hung, S. T. (2011). Pedagogical applications of Vlogs: An investigation into ESP learners' perceptions. British Journal of Educational Technology, 42(5), 736-746.Available at: https://doi.org/10.1111/j.1467-8535.2010.01086.x.

Krashen, S. D. (1982). Principles and practice in second language acquisition. Oxford: Pergamon Press.

Lim, H. L., \& Budin, M. (2014). Investigating the relationship between English language anxiety and the achievement of school based oral English test among Malaysian Form Four students. International Journal of Learning, Teaching and Educational Research, 2(1), 67-79.

MacIntyre, P. D., Noels, K. A., \& Clément, R. (1997). Biases in self-ratings of second language proficiency: The role of language anxiety. Language Learning, 47(2), 265-287.Available at: https://doi.org/10.1111/0023-8333.81997008.

Madzlan, N. A., \& Kesevan, H. (2018). ESL learners'perception of non-verbal behaviour as represented in silent comedy. International Journal of Education, 3(13), 85-91.

McCroskey, J. C. (2013). Personal report of public speaking anxiety (PRPSA) . Measurement Instrument Database for the Social Science. Retrieved from www.midss.ie.

McQuail, D. (2005). McQuail's mass communication theory (5th ed.). London: SAGE Publications.

Nurul, L. A. R. (2010). A study on second language speaking anxiety among UTM students. Universiti Teknologi Malaysia. Retrieved from http://www.fp.utm/my/epusatsumber/pdffail/ptkghdfwp2/p_2009_8820_fo13b49b69214066bb1d506dbe65d3e8.pdf.

Satar, H. M., \& Özdener, N. (2008). The effects of synchronous CMC on speaking proficiency and anxiety: Text versus voice chat. The Modern Language Journal, 92(4), 595-613.Available at: https://doi.org/10.1111/j.1540-4781.2008.00789.x.

Shih, R. C. (2010). Blended learning using video-based blogs: Public speaking for English as a second language students. Australasian Journal of Educational Technology, 26(6), 883-897.Available at: https://doi.org/10.14742/ajet.1048.

Siemens, G. (2005). Connectivism: A learning theory for the digital age. International Journal of Instructional Technology and Distance Learning, $2(1), 3-10$.

Watkins, J. (2012). Increasing student talk time through vlogging. Language Education in Asia, 3(2), 196-203.Available at: https://doi.org/10.5746/leia/12/v3/i2/a08/watkins.

Zhiping, D., \& Paramasivam, S. (2013). Anxiety of speaking English in class among international students in a Malaysian university. International Journal of Education and Research, 1(11), 1-16. 